\title{
Tumor angiogenesis and anti-angiogenic therapy in malignant gliomas revisited
}

\author{
Karl H. Plate $\cdot$ Alexander Scholz $\cdot$ Daniel J. Dumont
}

Received: 6 September 2012/Revised: 2 November 2012/ Accepted: 2 November 2012/Published online: 11 November 2012

(C) The Author(s) 2012. This article is published with open access at Springerlink.com

\begin{abstract}
The cellular and molecular mechanisms of tumor angiogenesis and its prospects for anti-angiogenic cancer therapy are major issues in almost all current concepts of both cancer biology and targeted cancer therapy. Currently, (1) sprouting angiogenesis, (2) vascular co-option, (3) vascular intussusception, (4) vasculogenic mimicry, (5) bone marrow-derived vasculogenesis, (6) cancer stem-like cell-derived vasculogenesis and (7) myeloid cell-driven angiogenesis are all considered to contribute to tumor angiogenesis. Many of these processes have been described in developmental angiogenesis; however, the relative contribution and relevance of these in human brain cancer remain unclear. Preclinical tumor models support a role for sprouting angiogenesis, vascular co-option and myeloid cell-derived angiogenesis in glioma vascularization, whereas a role for the other four mechanisms remains controversial and rather enigmatic. The antiangiogenesis drug Avastin (Bevacizumab), which targets VEGF, has become one of the most popular cancer drugs in the world. Anti-angiogenic therapy may lead to vascular normalization and as such facilitate conventional cytotoxic chemotherapy. However, preclinical and clinical studies suggest that anti-VEGF therapy using bevacizumab may also lead to a pro-migratory phenotype in therapy resistant glioblastomas and thus actively promote tumor invasion and recurrent tumor growth. This review focusses on
\end{abstract}

K. H. Plate $(\bowtie) \cdot$ A. Scholz

Institute of Neurology (Edinger Institute), Frankfurt University

Medical School, Frankfurt, Germany

e-mail: karl-heinz.plate@kgu.de

D. J. Dumont

Sunnybrook Research Institute, Sunnybrook Health Science

Center, Toronto, ON, Canada
(1) mechanisms of tumor angiogenesis in human malignant glioma that are of particular relevance for targeted therapy and (2) controversial issues in tumor angiogenesis such as cancer stem-like cell-derived vasculogenesis and bonemarrow-derived vasculogenesis.

\section{Introduction}

In his landmark 1971 publication, Folkman [41] developed the idea that tumor growth is angiogenesis dependent and described for the first time the potential prospects of antiangiogenic cancer therapy. From thereon, it took 13 years before fibroblast growth factor (FGF)-2, the first heparinbinding angiogenic growth factor, was identified and 18 years before vascular endothelial growth factor (VEGF), which by now has turned out to be the single most important angiogenesis factor in both health and disease, was described (for review see [38]). Napoleone Ferrara, one of the discoverers of VEGF, developed monoclonal antibodies to VEGF [70] that blocked tumor growth in vivo [71] and that paved the way for the development of bevacizumab, a monoclonal anti-VEGF antibody that is now used in a large number of clinical cancer trials, including glioblastoma, where anti-angiogenesis represents one treatment arm [104, 131]. It is now evident that the entire process of tumor-induced angiogenesis appears to be far more complex than initially envisioned [15]. Moreover, the idea that blockade of tumor angiogenesis is able to inhibit tumor growth in vivo has been confirmed in principal in both experimental and clinical settings; however, current evidence suggests that cancer cells are able to circumvent anti-angiogenic therapy and develop resistance to targeted mono-therapy $[7,129]$. 


\section{Cell biology of tumor angiogenesis}

In a recent Cell snapshot Jain and Carmeliet listed six different principal cellular mechanisms under the heading of tumor angiogenesis. These include (1) classical sprouting angiogenesis, (2) vascular co-option, (3) vessel intussusception, (4) vasculogenic mimicry, (5) bone marrow derived vasculogenesis and (6) cancer stem-like cell derived vasculogenesis [62]. Another important mechanism of tumor angiogenesis is angiogenesis driven by blood derived infiltrating myeloid cells, a process that recently received considerable attention. Whether the above listed mechanisms of tumor angiogenesis (for overview see Fig. 1) are all operational in human glioblastoma is not entirely clear. Here, we briefly discuss the above mentioned angiogenesis mechanisms and review the existing evidence for their role in glioma biology.

Angiogenesis, the sprouting of capillaries from preexisting vessels, has since long been considered the principal mechanism of brain vascularization, both during development and in brain cancer [80, 81, 111, 121]. A vascular sprout that is led by a filopodia-rich tip cell migrates toward an angiogenic stimulus (often VEGF) that is produced by tumor cells. Following the tip are a group of cells, entitled stalk cells, that divide, which promotes the elongation of the sprout (Fig. 2). Tip cells from two distinct sprouts may fuse to yield a larger sprout, a process that is thought to be modulated by the action of macrophages on these activated endothelial cells (Fig. 4). Thereafter, the newly formed vessel remodels to form a vascular lumen (that permits blood flow) and to attract mural cells that stabilize the vessel (reviewed in [16, 143]). Current evidence suggests that vascular sprouting represents a major mechanism of tumor angiogenesis. Analysis of cell division in glioblastoma, by MIB-1 staining, suggests that there are a considerable number of vascular endothelial cells undergo cell division suggesting that these cells may represent stalk cells. In addition to this, molecules typically expressed on endothelial tip cells such as VEGFR-2, Neuropilin-1, Angiopoietin-2 (Ang-2), Integrin- $\beta 1$ and others have been described to be present in glioma vessels in situ [11, 31, 114], implying that tip and stalk cell phenotypes co-exist in the glioblastoma vasculature.

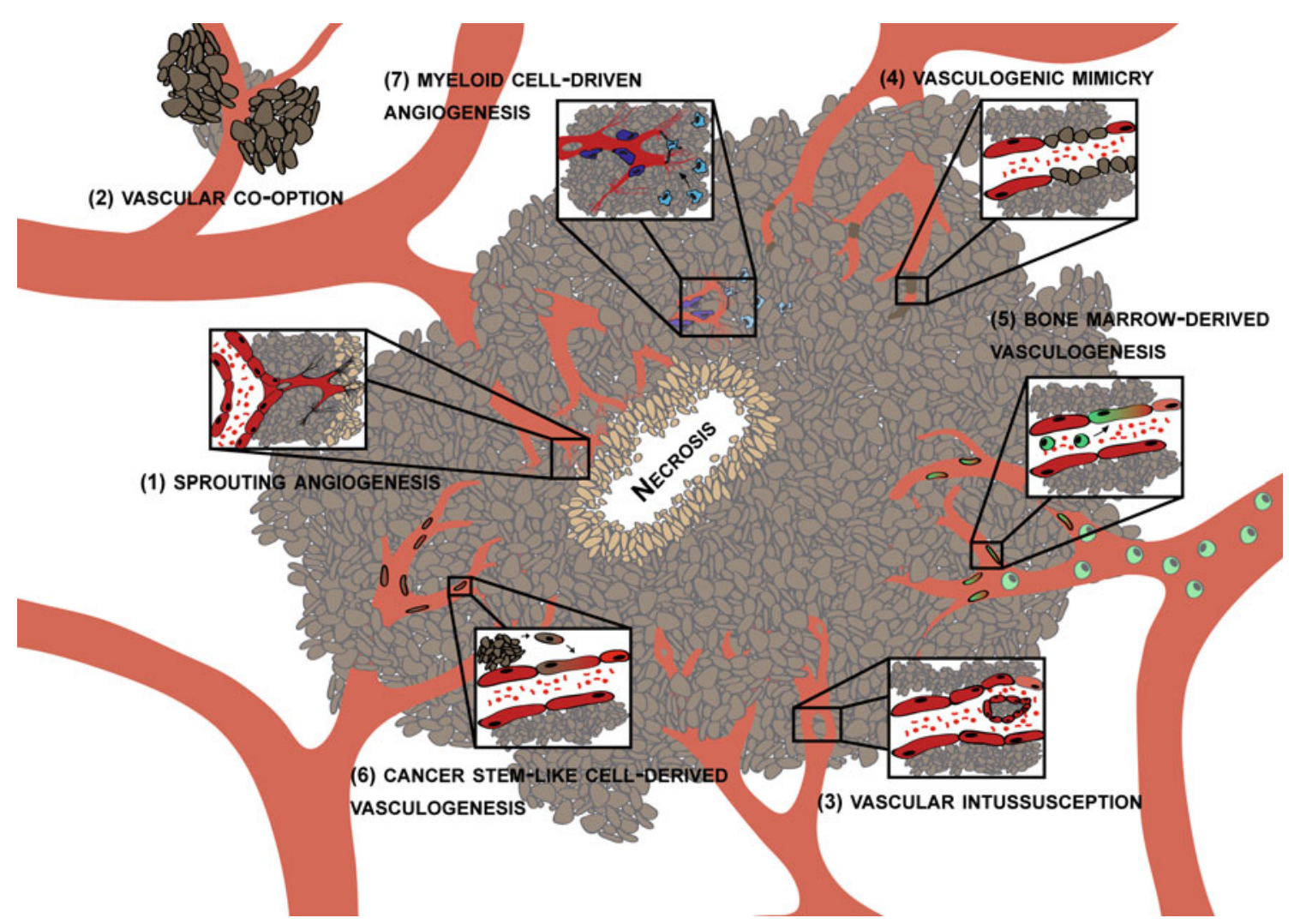

Fig. 1 Potential mechanisms of glioma angiogenesis. Currently, (1) sprouting angiogenesis, (2) vascular co-option, (3) vascular intussusecption, (4) vasculogenic mimicry, (5) bone marrow-derived vasculogenesis, (6) cancer stem-like cell derived vasculogenesis and (7) myeloid cell-driven angiogenesis are all considered to contribute to tumor angiogenesis. However, some of these mechanisms have initially been described in developmental angiogenesis and their relative contribution and relevance in human brain cancer is unclear (see text) 


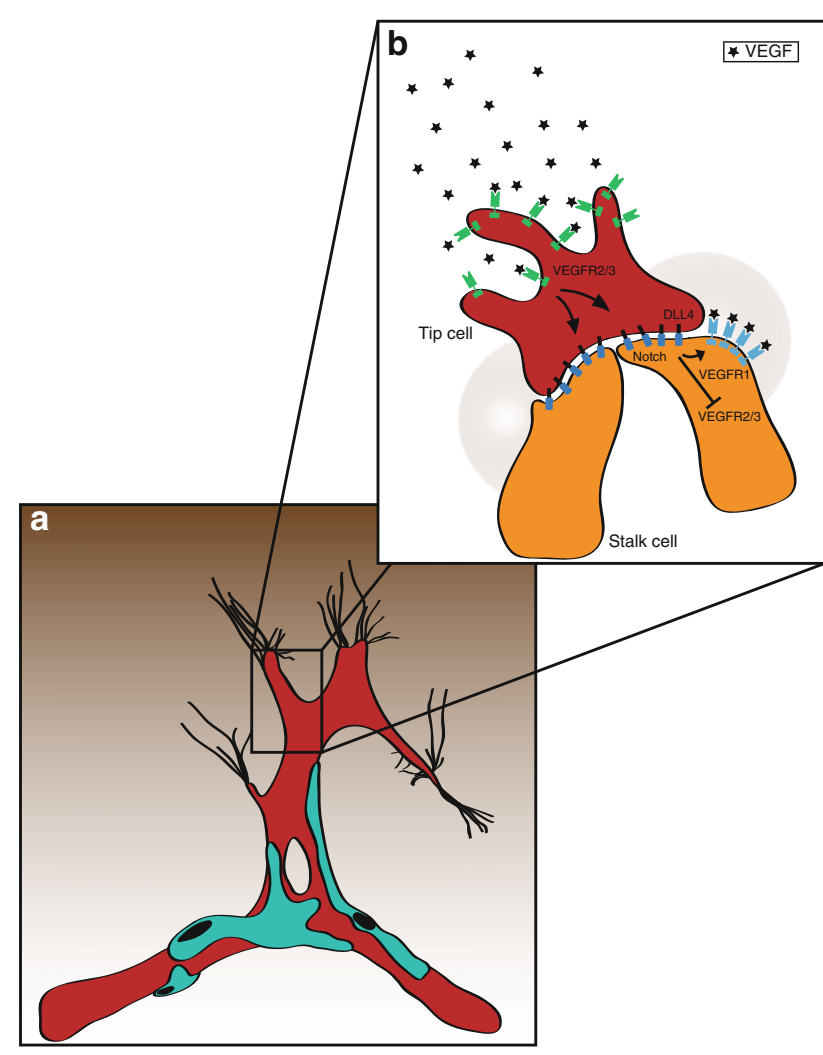

Fig. 2 VEGF and Notch regulate tip and stalk cell dynamics during vascular sprouting. a Angiogenic sprouting is initialized by VEGF signaling and spatially and temporally regulated by a VEGF gradient (brown). Endothelial tip cells exhibit numerous filopodia extensions sensing the environment for migration cues and are devoid of pericyte coverage (turquois). b Blowup showing the induction and maintenance of tip versus stalk cell identity. Tip cells are induced by VEGF (black) that binds to VEGFR2/3 (green) localized on the filopodia. VEGF-signaling in tip cells up-regulates Dl14 (black) and Notch1 (blue) ligand. Dll4-Notch signaling will in turn modulate VEGFR2/3 in adjacent cells, thereby inducing the stalk cell phenotype. Furthermore, VEGFR1 (light blue) becomes up-regulated and acts as a VEGF decoy receptor (shaded circular area) and helps maintaining the VEGF gradient

Vascular co-option describes the infiltration of tumor cells into normal tissue and the adoption of the pre-existing vasculature [56]. When one takes this into consideration, vascular co-option may be viewed as part of the invasive phenotype that is intrinsic to all diffuse gliomas-rather than an active vascular process. Invoking the process of vascular co-option aligns well with the known migratory pattern of tumor cells along vessels which has been observed in numerous experimental glioma models in rodents. Vascular co-option may facilitate the infiltration of human gliomas. Of note, anti-VEGF treatment may drive glioma cells to utilize the co-option pathway thereby circumventing the impact of anti-VEGF treatment resulting in an increase in the number of migrating glioma cells, that may use pre-existing vessels as scaffolds for their migration pathways (see below).
Vessel intussusception describes the formation of a new vessel by vascular invagination, intra-luminar pillar formation and splitting. Vascular intussusception has initially been described in physiological vascular development [32] but more recently has been expanded to experimental tumors. It has been suggested that sprouting angiogenesis may switch to vascular intussusception to allow rapid development of new vessels [119]. The molecular mechanisms that drive vascular intussusception are currently poorly understood and whether intussusception occurs or plays a role in human glioma or tumor biology in general is currently unclear.

Vasculogenic mimicry is defined as a process where tumor cells replace endothelial cells and form a vessel with a lumen This phenomenon was first described (mainly based on PAS staining) in a subset of aggressive uveal melanomas [95] and later in other types of cancer but its overall occurrence and significance, if any, is highly controversial. Moreover, it is unclear whether vasculogenic mimicry represents an active process (e.g., cancer cells actively forming the vascular lumen) or whether vasculogenic mimicry is a consequence of vessel regression. Vessel regression is part of the vascular remodeling process that takes place in development but can also occur in tumors (Fig. 2a). During development, a normal and wellorchestrated realignment of the balance between growth/ survival signals such as high levels of Ang-2 together with low levels of VEGF leads to vessel regression and endothelial cell apoptosis causing vessel pruning and vessel remodeling [50]. A similar situation (high levels of Ang-2 combined with low levels of VEGF) can occur in cancer after bevacizumab therapy and may therefore be responsible for intratumoral vessel regression. In addition to programmed vessel regression, cessation of blood flow due to development of shunts or the thrombosis of tumor vessels can lead to tumor vessel regression via downregulation of the transcription factor kruppel-like factor 2 (KLF2) and subsequent up-regulation of Ang-2 (Fig. 2b) [74, 145]. McDonald and colleagues have discussed the phenomenon of vasculogenic mimicry in detail and came to the conclusion that even in the prototype of cancer that shows vasculogenic mimicry, aggressive uveal melanomas, vascular channels are almost always lined by endothelial cells and not by cancer cells [98, 99], leading these authors generally doubt the significance of vasculogenic mimicry in tumor angiogenesis. Studies dealing with vasculogenic mimicry in human gliomas are sparse and mainly rely on PAS-staining to identify cancer cell-lined vascular channels. In one study, PAS-positive vascular channels devoid of CD34+ cells have been described in 2/45 human glioma specimens [155], and in 13 out of 101 samples in another study [89]. Recently, based on double-immunofluorescence staining, co-expression of GFAP (a marker for glioma 
cells) and VEGFR-2 (a marker for endothelial cells) has been reported in 7 out of 11 human GBM investigated and has been considered as evidence for vasculogenic mimicry [44], but this awaits confirmation. In summary, the functional and clinical relevance of vasculogenic mimicry appears questionable in light of the methodological problems encountered. Rather, we prefer to conclude from the data published that vasculogenic mimicry appears to be of little significance in glioblastoma angiogenesis, since most vessels appear to be lined by a proper endothelium on the luminal side.

Bone marrow-derived vasculogenesis describes the recruitment of circulating endothelial precursor cells to the tumor, their integration into the vessel wall and their terminal differentiation into an endothelial cell. From the onset of the original description of tumor vasculogenesis [2], this phenomenon has attracted a considerable amount of attention. This attention has stemmed from the fact that it has challenged the previous dogma that the postnatal vasculature (under both physiological and pathological conditions) can only proceed via angiogenesis but not vasculogenesis in order to adapt to altered physiological needs [121]. Mouse molecular studies that used chimeric mice with GFP-tagged bone marrow cells together with high-resolution confocal imaging and 3D-reconstruction revealed however that BM-derived endothelial cells in experimental gliomas represent only a small amount (less than $1 \%$ ) of all vascular endothelial cells [93]. However, it has been suggested that vasculogenesis is important for neovascularization after tumor irradiation [72]. Again, this issue has lead to a controversy since work from several laboratories suggests that bone marrow-derived cells do not incorporate into the vessel lumen to a significant extent but rather stay adjacent to the vessel, in a perivascular location [75]. These results suggest that bone marrow-derived cells support angiogenesis in a paracrine manner but presumably not by incorporation into the endothelial cell layer proper [76]. This imprecise use of the term "vasculogenesis" has facilitated the confusion in the literature about the process of tumor vasculogenesis [75]. Taken together, "real" tumor vasculogenesis appears to be a rare biological event that probably does not bear any clinical significance in human glioblastoma.

Cancer stem-like cell derived vasculogenesis: In 2010, two groups independently reported the transdifferentiation of GBM-derived stem-like cells into endothelial cells in vitro $[120,148]$. The authors showed further that a proportion of vascular cells within human GBM contained genetic alterations that are typically encountered in glioblastoma cells (such as EGFR amplification) and are typically not seen in vascular endothelial cells. One group even reported that the majority of GBM vascular cells contained genetic alterations typically found in tumor cells
[120]. The authors concluded that GBM-derived cancer stem-like cells can contribute to the vasculature by integrating into the vascular wall and transdifferentiate into endothelial cells, while retaining their genetic alterations. In contrast to this, recent work by Rodriguez [123] who examined GBM by detailed histological analysis demonstrated that in GBM (1) mutant vascular cells are extremely rare and (2) these cells are usually found in the perivascular space or vascular wall but were not lining the vessel lumen. Taken together, the existence of cancer stem-like cellderived vasculogenesis in human glioblastoma is highly controversial and at best appears to be a very rare event.

The participation of bone marrow derived cells in driving tumor angiogenesis has achieved considerable attention recently (for reviews see [47, 66]). In particular, monocytes/macrophages can polarize into phenotypes that exert different functions in vivo. In contrast to M1 monocytes/macrophages, that are anti-tumorigenic, M2polarized monocytes/macrophages are pro-angiogenic and thus drive tumor growth [135]. Current evidence suggests that monocytes/macrophages secrete a variety of protumorigenic and pro-angiogenic growth factors (including VEGF). Experimental studies in glioma models suggest that blocking of monocyte/macrophage recruitment and/or function may block glioma growth (see below). As such, monocytes/macrophages represent an attractive target for anti-angiogenic tumor therapy although the relevance of bone marrow driven angiogenesis in human glioma still needs to be determined.

\section{Angiogenic signaling pathways in glioblastoma}

Signaling pathways initiated from numerous growth factor receptors are known to play pivotal roles in developmental and tumor-mediated angiogenesis. In this review, we focus on three signaling pathways with a proven role in vascular biology and/or tumor angiogenesis that are currently being explored in clinical trials (Table 1) or represent major pharmaceutical targets that are under intense scrutiny. In addition to these angiogenic factors, further angiogenic signaling pathways are provided by axon guidance molecules that are known to play a role in both vascular and neuronal patterning (for recent review see [1, 37]. However, due to their prominent role in nervous system development and homeostasis it appears questionable whether these molecules will become targets for antiangiogenic glioma therapy (see below and [115]).

\section{VEGF signaling}

VEGF is the principal angiogenesis factor in both embryonic development and tumor growth (for review see [38]). 
Table 1 Current clinical trials targeting the VEGF/VEGFR or Ang/Tie2 signaling pathways in glioblastoma

\begin{tabular}{|c|c|c|c|c|c|c|}
\hline Compound & Target & Combination & Phase & NCT number & Status & Company and/or trial center \\
\hline \multirow[t]{2}{*}{ Aflibercept } & \multirow[t]{2}{*}{ VEGF } & \multirow[t]{2}{*}{$\begin{array}{l}\text { Temozolomide } \\
\text { Radiation }\end{array}$} & I & NCT00650923 & Active & $\begin{array}{l}\text { Sidney Kimmel } \\
\text { Comprehensive Cancer } \\
\text { Center }\end{array}$ \\
\hline & & & II & NCT00369590 & Completed & $\begin{array}{l}\text { Sidney Kimmel } \\
\text { Comprehensive Cancer } \\
\text { Center }\end{array}$ \\
\hline $\begin{array}{r}\text { AZD2171 (Cediranib } \\
\text { Maleate, Recentin) }\end{array}$ & VEGF & Bevacizumab & I & NCT00458731 & Active & $\begin{array}{l}\text { M.D. Anderson Cancer } \\
\text { Center }\end{array}$ \\
\hline \multirow[t]{8}{*}{ Bevacizumab } & \multirow[t]{8}{*}{ VEGF } & Temozolomide & II & NCT00590681 & Active & Genentech \\
\hline & & Erlotinib & II & NCT00671970 & Active & Genentech \\
\hline & & Irinotecan Voronistat & I & NCT00762255 & Active & Merck \\
\hline & & $\begin{array}{l}\text { Radiation } \\
\text { Temozolomide }\end{array}$ & II & NCT01478321 & Active & Northwestern University \\
\hline & & \multirow[t]{2}{*}{ Temozolomide } & II & NCT01013285 & Active & UCLA \\
\hline & & & II & NCT00271609 & Active & National Cancer Institute \\
\hline & & Temsirolimus & II & NCT00800917 & Completed & Roch/Pfizer \\
\hline & & Cetuximab Irinotecan & II & NCT00463073 & Completed & \\
\hline \multirow[t]{10}{*}{ Bevacizumab } & \multirow[t]{10}{*}{ VEGF } & Irinotecan & II & NCT00463203 & Completed & \\
\hline & & TPI287 & $\mathrm{I} / \mathrm{II}$ & NCT01582152 & Recruiting & Archer Biosciences, Inc. \\
\hline & & Voronistat & $\mathrm{I} / \mathrm{II}$ & NCT01266031 & Recruiting & Genentech \\
\hline & & Temozolomide & II & NCT01149850 & Recruiting & Genentech \\
\hline & & Radiosurgery & $\mathrm{I} / \mathrm{II}$ & NCT01086345 & Recruiting & $\begin{array}{l}\text { Case Comprehensive } \\
\text { Cancer Center }\end{array}$ \\
\hline & & Lomustine & II & NCT01067469 & Recruiting & $\begin{array}{l}\text { M.D. Anderson Cancer } \\
\text { Center }\end{array}$ \\
\hline & & $\begin{array}{l}\text { Stereotactic } \\
\quad \text { Radiotherapy }\end{array}$ & I & NCT01392209 & Recruiting & Genentech \\
\hline & & Lenalidomide & I & NCT01183663 & Recruiting & $\begin{array}{l}\text { M.D. Anderson Cancer } \\
\text { Center }\end{array}$ \\
\hline & & Rindopepimut/GM-CSF & II & NCT01498328 & Recruiting & Celldex Therapeutics \\
\hline & & Irinotecan & II & NCT00393094 & Terminated & National Cancer Institute \\
\hline AEE788 & $\begin{array}{l}\text { VEGFR, EGFR/ } \\
\text { ErbB2 }\end{array}$ & & $\mathrm{I} / \mathrm{II}$ & NCT00116376 & Completed & Novartis \\
\hline BIBF 1120 & $\begin{array}{l}\text { VEGFR, PDGFR, } \\
\text { FGFR }\end{array}$ & & II & NCT01251484 & Active & $\begin{array}{l}\text { Boehringer Ingelheim } \\
\text { Pharmaceuticals } \\
\text { University of } \\
\text { Copenhagen }\end{array}$ \\
\hline Pazopanib & $\begin{array}{l}\text { VEGFR-1/2/3, } \\
\text { PDGFR, c-Kit }\end{array}$ & Lapatinib & II & NCT00350727 & Completed & GlaxoSmithKline \\
\hline \multirow[t]{3}{*}{ AMG 386 (Trebanabnib) } & \multirow[t]{3}{*}{ Ang-1/2 } & Bevacizumab & $\mathrm{I} / \mathrm{II}$ & NCT01290263 & Suspended & Amgen \\
\hline & & & I & NCT01538095 & Recruiting & National Cancer Institute \\
\hline & & Bevacizumab & II & NCT01609790 & Recruiting & $\begin{array}{l}\text { National Cancer Institute } \\
(\mathrm{NCI})\end{array}$ \\
\hline PF- 04856884 (CVX-060) & Ang-2 & & II & NCT01225510 & Withdrawn & Pfizer \\
\hline
\end{tabular}

Ang Angiopoietin, $V E G F$ vascular endothelial growth factor, $V E G F R$ vascular endothelial growth factor receptor

Deletion of either VEGF or VEGFR-1 or VEGFR-2 leads to embryonic lethality in the mouse due to severe defects in the developing vascular system [14, 42, 43, 133]. A role for VEGF in cerebral vascularization is illustrated by analysis of the conditional deletion of VEGF in the nervous system using a Nestin-cre/VEGF flox binary transgenic mouse to specifically delete VEGF in all Nestin-expressing cells. Mice carrying this deletion have a severe phenotype where the primitive perineural vascular plexus is able to develop, but vascular sprouts do not penetrate into the primitive 
avascular neuroectoderm. These mice have an avascular brain that causes microcephaly and massive periventricular apoptosis [116].

In GBM, VEGF is highly up-regulated, in particular in perinecrotic pseudopalisading cells [113, 134]. A major driving force of VEGF expression in GBM appears to be tumor hypoxia since VEGF and other hypoxia-inducible genes such as HIF-1 alpha and LDH are expressed in the same cell type [156]. Data derived from The Cancer Genome Atlas (TCGA) (http://cancergenome.nih.gov) suggest that in GBM the entire VEGF/VEGF receptor system is predominantly orchestrated by the up-regulation of VEGF; however, the VEGF receptors-1, -2 and -3 are also up-regulated in the tumor vasculature. The vast majority of clinical trials that target tumor angiogenesis use drugs that target the VEGF signaling pathway, either by blocking VEGF or by interfering with VEGFR-2 signaling (see Table 1 and for review [100]). The most advanced VEGFspecific drug currently on the market is bevacizumab, a monoclonal antibody that blocks VEGF function. Bevacizumab is routinely used in combination with chemotherapy (e.g., irinotecan) for the treatment of recurrent glioblastoma [19, 142, 147]. Unfortunately, several recent clinical reports suggest that anti-VEGF treatment may in fact promote a pro-migratory cellular tumor phenotype in patients with recurrent glioblastoma (for example [24, 102]). Importantly, these clinical observations are supported by several pre-clinical studies that in principle show that anti-VEGF treatment in mice or rats promotes a pro-invasive phenotype and may even increase tumor metastasis [35, $68,107]$. A possible explanation for this phenomenon, which represents a major challenge and clinical drawback, might be the induction of hypoxia and up-regulation of hypoxia-inducible genes via the HIF-1 alpha pathway [117]. Indeed, it has been suggested that hypoxia-mediated migration of tumor cells is responsible for the development of "pseudopalisading" glioma cells surrounding necroses, a histological hallmark of glioblastoma [10]. As such, these cells may represent glioma cells that are hypoxic and "try to escape" from a low oxygen microenvironment $[110,114]$. The molecular mechanisms underlying this event are only partly understood. The protooncogene c-met, for example, has been shown to be up-regulated by hypoxia and to trigger invasion [9, 36, 108]. Recently, it has been suggested that c-met is activated in GBM upon bevacizumab treatment in a VEGFR-2 and phosphotyrosine phosphatase (PTP1B)dependent manner. In this scenario, bevacizumab-induced depletion of VEGF reduces PTP1B activity and promotes c-met phosphorylation. This mechanism may therefore account at least in part for the observed therapy-induced switch to a pro-migratory phenotype after bevacizumab treatment [20, 92]. However, this putative mechanism requires the co-expression of c-met together with VEGFR-2 on glioma cells in vivo. Whereas VEGFR-2 can be readily detected in glioma cell lines in vitro, most studies suggest that in both murine and human glioma specimens in vivo expression of VEGFR-2 is mainly confined to vascular endothelial cells $[51,52,77,87,112-114,136]$, and potentially to a subset of cancer stem-like cells [49]. As such, it remains currently unclear whether the mechanism of bevacizumab-induced migration of glioma cells as proposed by $\mathrm{Lu}$ et al. is of relevance in human glioblastoma in vivo.

\section{Tie2/Angiopoietin signaling}

Pharmacological interference of the Tie2/Angiopoietin signaling pathway has received considerable attention recently (for review see [17, 58]). Several pre-clinical studies have shown that modulation of this pathway leads to alterations in vascular morphology and inhibition of tumor growth. Several types of angiopoietin inhibitors are now in phase I-III clinical trials (Table 1). The Tie2 receptor tyrosine kinase is expressed in endothelial cells and a subset of hematopoietic cells during development [34]. Similar to VEGF receptors, Tie2 is critical for normal vascular development [33]; however, in contrast to VEGF receptors that are down-regulated after embryonic angiogenesis has ceased, Tie2 appears to be constitutively expressed and phosphorylated in the adult vasculature [150]. This constitutive expression and activation suggests that signaling via Tie2 is important for the homeostasis of the mature vasculature (Fig. 3). Indeed, Tie2 signaling promotes stable vessels that are covered by pericytes. Tie 2 is bound by three different ligands that engage the same binding site on the receptor. Angiopoietin-1 (Ang-1) and Angiopoietin-2 (Ang-2) are the first ligands to be discovered and are the best studied, whereas the function of Ang4 is less understood. These ligands are thought to bind to Tie2 with roughly similar affinities and cause receptor activation [144]. In addition to Tie2, integrins serve as receptors for angiopoietins. A major observation has been that Ang-1 acts as a stimulating ligand for the Tie2 RTK that leads to receptor phosphorylation, whereas Ang-2 inhibits Tie2 phosphorylation, even in the presence of Ang1 [64, 94]. Ang-1 can "seal" vessels in vivo and decrease vascular permeability [61]. Interestingly, the major regulator of the entire Tie2/Angiopoietin signaling pathway appears to be Ang-2. TCGA data for glioblastoma reveal that Ang-2 is up-regulated to a much higher extent than Ang-1, suggesting that Tie2 signaling is blocked in glioblastoma (http://cancergenome.nih.gov). The consequences of blocking Tie 2 signaling in vivo, as evidenced by several pre-clinical studies, appears to be a shift towards an immature vasculature, whereas Ang-1 appears to "normalize" the vasculature (see below). In addition to an impact on angiogenesis, Ang-2 was shown to mediate a 


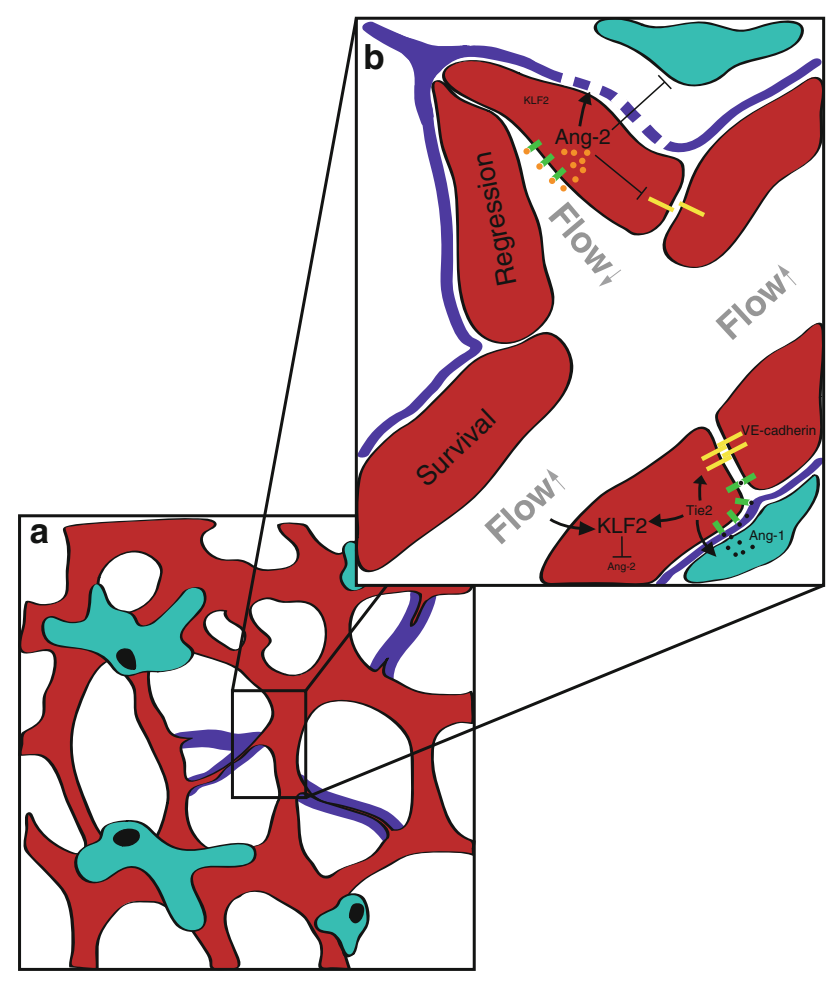

Fig. 3 Involvement of Angiopoietins during vascular regression. a Vascular regression occurs under both, pathological and physiological settings and is characterized by local pericyte loss (turquois) and the disappearance of endothelial cells, leaving an empty basement membrane sleeve ("ghost vessels"/blue). b During vascular homeostasis shear stress is inducing Kruppel-like factor 2 (KLF2), a negative regulator of Angiopoietin-2 (Ang-2). Furthermore, Ang-1 (black) is secreted by mural cells into the extra cellular matrix (ECM/ blue) and can then bind to endothelial expressed Tie2 (green) that will translocate to the cell-cell junctions upon Ang-1 binding forming homodimers in trans. Tie2 signaling further up-regulates KLF2 and stabilizes junctional molecules such as VE-cadherin (yellow). During vascular regression the occlusion of vessels leads to disturbed and reduced blood flow leading to KLF2 down-regulation. Ang-2 (orange) in turn becomes upregulated and triggers the dissociation of pericytes, the degradation of the basement membrane by inducing matrix metalloproteases (MMPs) and interferes with endothelial cell integrity

pro-inflammatory phenotype. In Ang-2 null mice the inflammatory response to stimuli such as TNF- $\alpha$ was greatly diminished when compared to controls [39]. Vice versa, in mice engineered to express an inducible form of Ang-2 in the vasculature, myeloid cells increased significantly over time in almost all organs, even without any pathological stimulus [128]. These findings suggest that Ang- 2 on its own is able to orchestrate an inflammatory response by specifically recruiting myeloid cells-and leaving lymphocytes behind (reviewed in [69]). Moreover, since Ang-2 is highly expressed in glioblastoma vessels [141], Ang-2 up-regulation may also account—at least in part-for the attraction of myeloid cells of the monocyte/ macrophage lineage to human gliomas. As such, inhibiting
Ang-2 may have at least two different effects on tumor growth: (1) a shift of balance towards mature vessels (e.g., vascular normalization) and subsequent decrease of intratumoral hypoxia (2) inhibition of monocyte/macrophage recruitment to tumors $[57,59,86,97]$.

Notch signaling pathway

The Notch signaling pathway plays an important role in organ development and recently has also received considerable attention in the vascular biology field recently (for review see $[8,78,122])$. Of the four Notch receptors, Notch 1 and Notch 4 are expressed on endothelial cells but Notch1 appears to be the most important for developmental angiogenesis. Similar to their receptors, Notch ligands are membrane-bound. Delta-like ligand4 (Dll4) appears to be the most important Notch ligand for stimulating angiogenesis, whereas another ligand, Jagged1, negatively regulates angiogenesis by competing with Dll4 [4, 78]. Notch in concert with VEGF signaling appears to be instrumental in the tip cell versus stalk cell fate decision that is essential for the initiation of sprouting angiogenesis (see Fig. 2). VEGF-A induces signaling in VEGFR-2 and -3 , which are expressed in the tip cells leading to up-regulation of Dll4 and subsequent activation of Notch signaling in adjacent endothelial stalk cells. This signaling cascade places the Notch signaling pathway downstream of VEGFR-2 and R-3 signaling in endothelial cells. Once activated, Notch signaling can ultimately provide negative feedback on VEGFR signaling by up-regulating VEGFR-1 but inhibiting VEGFR-2 and R-3 expression in stalk cells, this signaling circuit provides a way for regulating tip versus stalk cell fate decisions [5]. The up-regulation of VEGFR-1, which acts as a decoy receptor, further contributes to the maintenance of the VEGF gradient. Blocking of Dll4-Notch interaction leads to hypervascular tumors that are nevertheless inhibited in their growth. This phenomenon has been entitled the "delta-paradox" and is probably based on the excessive production of non-functional vessels (e.g., tumor vessel abnormalization) [78]. Since Dll4 has been primarily detected in glioblastoma vasculature and not in glioma cells [65], targeting Dll4 by neutralizing antibodies is considered a potential antiangiogenic tumor therapy. However, safety concerns have been arisen since it has been reported that in preclinical models, chronic Dl14 blockade abnormally activates endothelial cells and causes vascular neoplasms [152].

\section{The concept of vascular normalization}

The concept of "vascular normalization" has been introduced by Jain [60]. This concept states that anti-angiogenic 
(e.g., Bevacizumab) treatment merely affects the immature vasculature and leaves the mature vessels unaltered. Indeed, it has been shown that VEGF withdrawal leads to selective ablation of immature blood vessels [6]. As such, a "normalized" vasculature results as a consequence of antiVEGF treatment, leading to increased perfusion of the tumor and subsequent increase of oxygenation. Vascular normalization is thought to interrupt the vicious circle that is driven by hypoxia and that leads to up-regulation of VEGF, resulting in the growth of immature-partly unperfused-vessels and a subsequent increase in tumor hypoxia [23]. Some researchers believe that vessel normalization followed by cytotoxic chemotherapy and/or radiotherapy should be the ultimate goal of any antiangiogenic therapy [62]. Indeed, in an experimental glioma model, intratumoral vascular normalization restored bloodbrain barrier properties by suppressing edema formation [118] and a clinical study showed increased blood perfusion in GBM after anti-angiogenic therapy [138]. In order to achieve vascular normalization, several potential targets beside anti-VEGF therapy have been identified that include (1) Tie2/Angiopoietin signaling (see above), (2) prolylhydroxylases, which are upstream of the HIF-signaling pathway [23], (3) blockade of the VEGF receptor-1 ligand placenta growth factor (PIGF) [40], (4) blocking of TGF- $\beta$ signaling [31] and (5) increase of vascular wnt/B-catenin signaling [118].

\section{The role of myeloid cells in tumor angiogenesis}

Current studies suggest that infiltrating myeloid cells contribute significantly to tumor angiogenesis, presumably by secreting pro-angiogenic factors including VEGF, stromalderived factor-1 (SDF-1) and others (Fig. 4, for review see [47, 101]). Grunewald et al. [48] have shown that myeloid cells are (1) recruited to tumors, (2) "educated" by the tumor microenvironment and (3) support tumor growth by secretion of SDF-1. In another study, chimeric mice were generated by transplanting bone marrow from VEGFR-1 signaling deficient mice into lethally irradiated wild-type mice. When Gl261 glioma cells were transplanted intracranially into these mice, tumor growth was significantly inhibited when compared to mice harboring a normal bone marrow. Subsequent studies showed that VEGFR-1 signaling deficient bone marrow chimeras displayed a defect in monocyte migration leading to significant lower amount of myeloid cells in the tumor tissue [67]. In a preclinical study, myeloid cell infiltration has been shown to be associated with tumor progression after anti-angiogenic therapy [109]. In a clinical study, a decrease in the number of VEGFR-1 + monocytes in the blood correlated with improved response after bevacizumab treatment [25]. Most

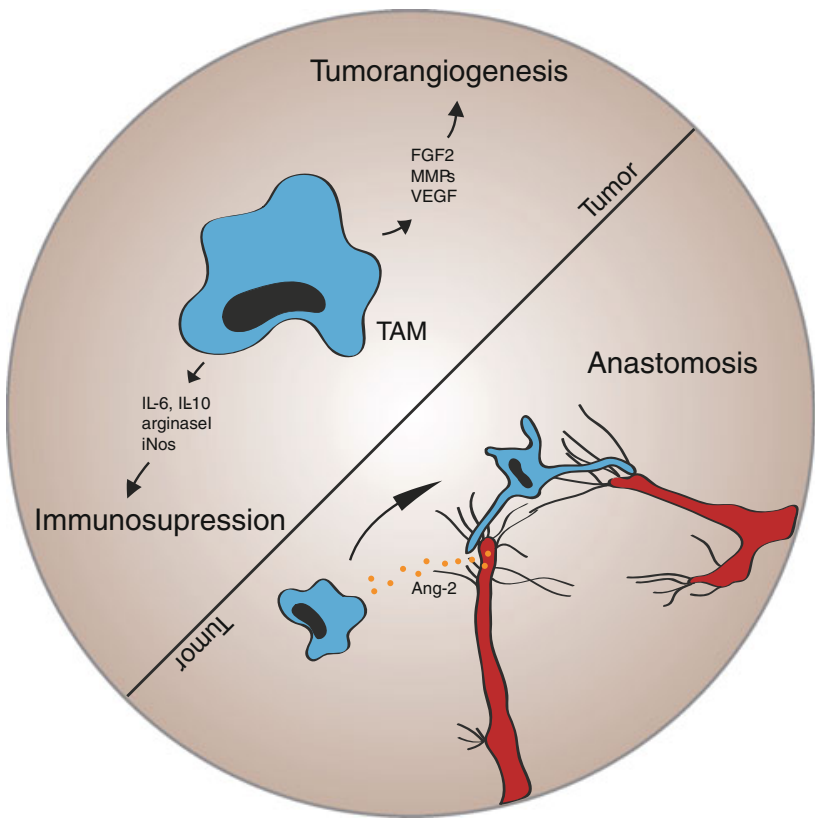

Fig. 4 The role of tumor-associated macrophages (TAMs) during tumor angiogenesis. TAMs (blue) can promote tumor growth in at least two different ways: 1. TAMs, actively suppress the hosts immune response to tumors by secretion of immunosuppressive mediators, such as IL-6 and IL-10. 2. TAMs are a significant source of angiogenic factors (e.g., FGF2, MMPs, VEGF) that promote tumor neovessel formation and thereby contribute to malignant progression. Macrophages are thought to participate in and support the process of anastomosis, the fusion of two vascular sprouts to establish a direct connection. During this setting, macrophages (blue) can be found intimately associated with endothelial tip cells (red). It is hypothesized that their recruitment to sites of vessel fusion is driven by tip cell secreted Ang-2 (orange) that can attract macrophages in a Tie2dependent or Tie-2 independent pathway, with the latter being mediated by beta2-integrins

of the myeloid cells that support tumor growth through the stimulation of angiogenesis appear to be monocytes/macrophages with M2 polarity (TAMs, tumor-associated macrophages) [135]. In contrast, bone marrow-derived non-hematopoietic mesenchymal stem cells may in fact suppress glioma growth through the inhibition of angiogenesis [54]. Interestingly, one distinct subtype of monocytes with particular importance for tumor angiogenesis and immunosuppression seems to be Tie2expressing monocytes (TEMs) [28]. TEMs represent a subset of circulating blood monocytes that are recruited from the circulation into tumors and locally support tumor growth in a paracrine manner [88]. Although the number of TEMs within a tumor appears relatively small (e.g., $<10 \%$ of infiltrating monocytes express Tie2) [21], loss of function studies using suicide gene approaches have shown that the specific depletion of TEMs is able to block tumor angiogenesis and tumor growth [29]. The number of infiltrating macrophages has been shown to be of prognostic relevance in breast cancer [85], rectal cancer [132], classic 
Hodgkin's lymphoma [139], adenocarcinoma of the lung [157] and hepatocellular carcinoma [27, 96]. Therefore, both TEMs and TAMs clearly have evolved as novel targets for anti-angiogenic cancer therapy [26, 66].

\section{Future prospects for anti-angiogenic therapy}

The first specific anti-angiogenic drug that received FDA approval in 2004 was bevacizumab, a neutralizing monoclonal antibody to VEGF. Bevacizumab is widely used in different types of cancer and significantly inhibits tumor growth in many cancer types (see Table 1 for current antiangiogenesis trials in glioblastoma). However, drugs that interfere with the function of the vascular system may also cause-sometimes severe-undesired effects [3, 84]. VEGFR-2 is not only expressed on endothelial cells but also on hemangioblasts and angioblasts [121] and in the nervous system (see below). Documented undesired effects of bevacizumab therapy include hypertension, induction of bleeding disorders and deep venous thrombosis [100, 103]. Chronic inhibition of the Notch pathway by Dll4 blockade using inhibitory antibodies may even lead to the induction of vascular neoplasms [152]. In addition, many vascular growth factors have been shown to be involved in the development and homeostasis of the nervous system by directly interacting with neurons (for review see [37, 115, 124, 125]). VEGF, for example, acts as a survival factor for neurons in vitro and in vivo and promotes neurogenesis, most likely through interaction with VEGFR-2 expressed on neurons [13, 22, 63, 127, 149, 153]. Partial deletion of VEGF in mice leads to loss of motoneurons and subsequently to a phenotype that highly resembles amyotrophic lateral sclerosis (ALS) in humans [106]. Indeed, polymorphisms in the vegfa gene are associated with a higher risk to develop ALS in humans [83] and delivery of recombinant VEGF has been used successfully to protect motoneurons in a rat model of ALS [140]. Currently, intracerebroventricular delivered VEGF is in clinical phase I/II trial for patients with ALS. Further, in line with a direct effect of VEGF on the nervous system, anti-VEGF receptor treatment has been reported to lead a painful sensory neuropathy [146].

In addition to the above-mentioned adverse effects of anti-VEGF treatment, pre-clinical and clinical reports suggest that cancer cells may develop resistance to antiangiogenic therapy by different mechanisms that include (1) switch to a pro-migratory phenotype, (2) up-regulation of other pro-angiogenic molecules [151] and (3) the increased recruitment of myeloid cells that support tumor growth (reviewed in [7, 66, 129]). As such, novel therapies are currently under development in both academia and pharmaceutical companies that include (1) novel VEGF inhibitors such as the VEGF trap [46, 55], (2) drugs that target the Tie2/Angiopoietin signaling pathway (reviewed in $[17,58])$, (3) double inhibition of VEGF and angiopoietins [12, 18, 73], (4) double inhibition of VEGF and c-met [130, 154], (5) inhibition of PlGF [30, 40] and (6) drugs that block myeloid cell recruitment and/or their polarization [91], among others. However, it has been suggested that intratumoral vessel are heterogenous and that, for example, VEGF-dependent and -independent vessels may co-exist within a given tumor [137]. These observations speak in favor of a multi-modal therapy that may combine different types of anti-angiogenic therapy or anti-angiogenic therapy together with cytotoxic therapy. The integrin inhibitor cilengitide, for example, targets both tumor cells and the vasculature [105], and is now in phase III clinical trial for glioblastoma patients [79, 126]. In our personal view, targeting the Tie 2 signaling pathway by blocking Ang-2 or stimulating Ang-1 (or both simultaneously) may be particularly promising since three mechanisms of tumor angiogenesis may be targeted similarly: (1) sprouting angiogenesis and (2) myeloid cell infiltration may be blocked, whereas (3) vascular normalization will be enhanced [17, 58]. Further, reported side effects of Ang-2 blocking appear to be sparse compared to other anti-angiogenic therapies employed [53, 82]. However, this has to be proven further in the clinical trials that are currently under way. It may also be necessary to stratify patients so that those that have a shift in the Ang-1/Ang-2 balance or other angiogenic factors are identified and the appropriate therapy initiated. For example, the monitoring of expression patterns of angiogenesis factors and their receptor in the tumor biopsy or the evaluation of biomarkers in the serum or cerebrospinal fluid of patients may provide useful indicators of a tumor's susceptibility to a particular targeted therapy [100]. Promising biomarkers that may indicate therapy responsiveness in anti-angiogenic therapy include serum Ang-2 levels and the number of circulating VEGFR-1 + monocytes [25, 45, 90]. It will be exciting to watch whether any of the newly developed therapies will be able to significantly affect survival of brain cancer patients.

Acknowledgments We are grateful to Prof. Michel Mittelbronn for his help in obtaining and interpreting data derived from the The Cancer Genome Atlas (TCGA). The work of the corresponding author is supported by (1) Deutsche Forschungsgemeinschaft (DFG): (a) Collaborative Research Center (SFB/TR23) grants B7, C1 and C4, (b) Excellence Cluster Cardiopulmonary-Systems (ECCPS), and (2) Helmholtz Society/BMBF (a) Deutsches Konsortium für Translationale Krebsforschung (DKTK), (b) Deutsches Zentrum für HerzKreislauf-Forschung (DZHK). D.J.D. is the Canadian Research Chair for Angiogenic and Lymphangiogenic Signaling; Funding was provided by the Heart and Stroke Foundation of Canada (NA5425).

Open Access This article is distributed under the terms of the Creative Commons Attribution License which permits any use, distribution, and reproduction in any medium, provided the original author(s) and the source are credited. 


\section{References}

1. Adams RH, Eichmann A (2010) Axon guidance molecules in vascular patterning. Cold Spring Harb Perspect Biol 2(5):a001875

2. Asahara T, Murohara T, Sullivan A, Silver M, van der Zee R, Li T, Witzenbichler B, Schatteman G, Isner JM (1997) Isolation of putative progenitor endothelial cells for angiogenesis. Science 275(5302):964-967

3. Belcik JT, Qi Y, Kaufmann BA et al (2012) Cardiovascular and systemic microvascular effects of anti-vascular endothelial growth factor therapy for cancer. J Am Coll Cardiol 60(7):618625

4. Benedito R, Roca C, Sörensen I, Adams S, Gossler A, Fruttiger M, Adams RH (2009) The notch ligands Dll4 and Jagged1 have opposing effects on angiogenesis. Cell 137(6):1124-1135

5. Benedito R, Rocha SF, Woeste M, Zamykal M, Radtke F, Casanovas O, Duarte A, Pytowski B, Adams RH (2012) Notchdependent VEGFR3 upregulation allows angiogenesis without VEGF-VEGFR2 signalling. Nature 484(7392):110-114

6. Benjamin LE, Hemo I, Keshet E (1998) A plasticity window for blood vessel remodelling is defined by pericyte coverage of the preformed endothelial network and is regulated by PDGF-B and VEGF. Development 125(9):1591-1598

7. Bergers G, Hanahan D (2008) Modes of resistance to antiangiogenic therapy. Nat Rev Cancer 8(8):592-603

8. Blanco R, Gerhardt H (2012) VEGF and Notch in tip and stalk cell selection. Cold Spring Harb Perspect Med October 1-20 (published online)

9. Bottaro DP, Liotta LA (2003) Cancer: out of air is not out of action. Nature 423(6940):593-595

10. Brat DJ, Castellano-Sanchez AA, Hunter SB, Pecot M, Cohen C, Hammond EH, Devi SN, Kaur B, Van Meir EG (2004) Pseudopalisades in glioblastoma are hypoxic, express extracellular matrix proteases, and are formed by an actively migrating cell population. Cancer Res 64(3):920-927

11. Broholm H, Laursen H (2004) Vascular endothelial growth factor (VEGF) receptor neuropilin-1's distribution in astrocytic tumors. APMIS 112(4-5):257-263

12. Brown JL, Cao ZA, Pinzon-Ortiz M et al (2010) A human monoclonal anti-ANG2 antibody leads to broad antitumor activity in combination with VEGF inhibitors and chemotherapy agents in preclinical models. Mol Cancer Ther 9(1):145-156

13. Cao L, Jiao X, Zuzga DS, Liu Y, Fong DM, Young D, During MJ (2004) VEGF links hippocampal activity with neurogenesis, learning and memory. Nat Genet 36(8):827-835

14. Carmeliet P, Ferreira V, Breier G et al (1996) Abnormal blood vessel development and lethality in embryos lacking a single VEGF allele. Nature 380(6573):435-439

15. Carmeliet P, Jain RK (2011) Molecular mechanisms and clinical applications of angiogenesis. Nature 473(7347):298-307

16. Carmeliet P, De Smet F, Loges S, Mazzone M (2009) Branching morphogenesis and antiangiogenesis candidates: tip cells lead the way. Nat Rev Clin Oncol 6(6):315-326

17. Cascone T, Heymach JV (2012) Targeting the Angiopoietin/ Tie2 pathway: cutting tumor vessels with a double-edged sword? J Clin Oncol 30(4):441-444

18. Chae SS, Kamoun WS, Farrar CT, Kirkpatrick ND, Niemeyer E, de Graaf AMA, Sorensen AG, Munn LL, Jain RK, Fukumura D (2010) Angiopoietin-2 interferes with anti-VEGFR2-induced vessel normalization and survival benefit in mice bearing gliomas. Clin Cancer Res 16(14):3618-3627

19. Chamberlain MC (2011) Bevacizumab for the treatment of recurrent glioblastoma. Clin Med Insights Oncol 5:117-129

20. Claesson-Welsh L (2012) Receptor talk and tumor cell walk in glioblastoma. Cancer Cell 22(1):1-2
21. Coffelt SB, Tal AO, Scholz A et al (2010) Angiopoietin-2 regulates gene expression in TIE2-expressing monocytes and augments their inherent proangiogenic functions. Cancer Res 70(13):5270-5280

22. Darland DC, Cain JT, Berosik MA, Saint-Geniez M, Odens PW, Schaubhut GJ, Frisch S, Stemmer-Rachamimov A, Darland T, D'Amore PA (2011) Vascular endothelial growth factor (VEGF) isoform regulation of early forebrain development. Dev Biol 358(1):9-22

23. De Bock K, Cauwenberghs S, Carmeliet P (2010) Vessel abnormalization: another hallmark of cancer? Molecular mechanisms and therapeutic implications. Curr Opin Genet Dev 21(1): $1-7$

24. de Groot JF, Fuller G, Kumar AJ, Piao Y, Eterovic K, Ji Y, Conrad CA (2010) Tumor invasion after treatment of glioblastoma with bevacizumab: radiographic and pathologic correlation in humans and mice. Neuro Oncol 12(3):233-242

25. de Groot JF, Piao Y, Tran H et al (2011) Myeloid biomarkers associated with glioblastoma response to anti-VEGF therapy with aflibercept. Clin Cancer Res 17(14):4872-4881

26. De Palma M, Lewis CE (2011) Cancer: macrophages limit chemotherapy. Nature 472(7343):303-304

27. De Palma M, Coukos G, Semela D (2012) TIE2-expressing monocytes: A novel cellular biomarker for hepatocellular carcinoma? Hepatology. doi:10.1002/hep.26025

28. De Palma M, Murdoch C, Venneri MA, Naldini L, Lewis CE (2007) Tie2-expressing monocytes: regulation of tumor angiogenesis and therapeutic implications. Trends Immunol 28(12):519-524

29. De Palma M, Venneri MA, Galli R, Sergi LS, Politi LS, Sampaolesi M, Naldini L (2005) Tie2 identifies a hematopoietic lineage of proangiogenic monocytes required for tumor vessel formation and a mesenchymal population of pericyte progenitors. Cancer Cell 8(3):211-226

30. Dewerchin M, Carmeliet P (2012) PlGF: a multitasking cytokine with disease-restricted activity. Cold Spring Harb Perspect Med. doi:10.1101/cshperspect.a011056

31. Dieterich LC, Mellberg S, Langenkamp E et al (2012) Transcriptional profiling of human glioblastoma vessels indicates a key role of VEGF-A and TGF $\beta 2$ in vascular abnormalization. J Pathol. doi:10.1002/path.4072

32. Djonov V, Schmid M, Tschanz SA, Burri PH (2000) Intussusceptive angiogenesis: its role in embryonic vascular network formation. Circ Res 86(3):286-292

33. Dumont DJ, Gradwohl G, Fong GH, Puri MC, Gertsenstein M, Auerbach A, Breitman ML (1994) Dominant-negative and targeted null mutations in the endothelial receptor tyrosine kinase, tek, reveal a critical role in vasculogenesis of the embryo. Genes Dev 8(16):1897-1909

34. Dumont DJ, Yamaguchi TP, Conlon RA, Rossant J, Breitman ML (1992) tek, a novel tyrosine kinase gene located on mouse chromosome 4, is expressed in endothelial cells and their presumptive precursors. Oncogene 7(8):1471-1480

35. Ebos JML, Lee CR, Cruz-Munoz W, Bjarnason GA, Christensen JG, Kerbel RS (2009) Accelerated metastasis after short-term treatment with a potent inhibitor of tumor angiogenesis. Cancer Cell 15(3):232-239

36. Eckerich C, Zapf S, Fillbrandt R, Loges S, Westphal M, Lamszus K (2007) Hypoxia can induce c-Met expression in glioma cells and enhance SF/HGF-induced cell migration. Int $\mathrm{J}$ Cancer 121(2):276-283

37. Eichmann A, Thomas J-L (2012) Molecular parallels between neural and vascular development. Cold Spring Harb Perspect Med. doi:10.1101/cshperspect.a006551

38. Ferrara N (2002) VEGF and the quest for tumour angiogenesis factors. Nat Rev Cancer 2(10):795-803 
39. Fiedler U, Reiss Y, Scharpfenecker M et al (2006) Angiopoietin2 sensitizes endothelial cells to TNF-alpha and has a crucial role in the induction of inflammation. Nat Med 12(2):235-239

40. Fischer C, Jonckx B, Mazzone M et al (2007) Anti-PlGF inhibits growth of $\operatorname{VEGF(R)-inhibitor-resistant~tumors~without~affecting~}$ healthy vessels. Cell 131(3):463-475

41. Folkman J (1971) Tumor angiogenesis: therapeutic implications. N Engl J Med 285(21):1182-1186

42. Fong GH, Rossant J, Gertsenstein M, Breitman ML (1995) Role of the Flt-1 receptor tyrosine kinase in regulating the assembly of vascular endothelium. Nature 376(6535):66-70

43. Fong GH, Zhang L, Bryce DM, Peng J (1999) Increased hemangioblast commitment, not vascular disorganization, is the primary defect in flt-1 knock-out mice. Development 126(13):3015-3025

44. Francescone R, Scully S, Bentley B, Yan W, Taylor SL, Oh D, Moral L, Shao R (2012) Glioblastoma-derived tumor cells induce vasculogenic mimicry through Flk-1 protein activation. J Biol Chem 287(29):24821-24831

45. Goede V, Coutelle O, Neuneier J et al (2010) Identification of serum Angiopoietin-2 as a biomarker for clinical outcome of colorectal cancer patients treated with bevacizumab-containing therapy. Br J Cancer 103(9):1407-1414

46. Gomez-Manzano C, Holash J, Fueyo J, Xu J, Conrad CA, Aldape KD, de Groot JF, Bekele BN, Yung WKA (2008) VEGF Trap induces antiglioma effect at different stages of disease. Neuro Oncol 10(6):940-945

47. Grivennikov SI, Greten FR, Karin M (2010) Immunity, inflammation, and cancer. Cell 140(6):883-899

48. Grunewald M, Avraham I, Dor Y, Bachar-Lustig E, Itin A, Yung S, Chimenti S, Landsman L, Abramovitch R, Keshet E (2006) VEGF-induced adult neovascularization: recruitment, retention, and role of accessory cells. Cell 124(1):175-189

49. Hamerlik P, Lathia JD, Rasmussen R et al (2012) Autocrine VEGF-VEGFR2-Neuropilin-1 signaling promotes glioma stemlike cell viability and tumor growth. J Exp Med 209(3):507-520

50. Hanahan D (1997) Signaling vascular morphogenesis and maintenance. Science 277(5322):48-50

51. Hatva E, Kaipainen A, Mentula P, Jääskeläinen J, Paetau A, Haltia M, Alitalo K (1995) Expression of endothelial cell-specific receptor tyrosine kinases and growth factors in human brain tumors. Am J Pathol 146(2):368-378

52. He T, Smith N, Saunders D et al (2011) Molecular MRI assessment of vascular endothelial growth factor receptor-2 in rat C6 gliomas. J Cell Mol Med 15(4):837-849

53. Herbst RS, Hong D, Chap L et al (2009) Safety, pharmacokinetics, and antitumor activity of AMG 386, a selective angiopoietin inhibitor, in adult patients with advanced solid tumors. J Clin Oncol 27(21):3557-3565

54. Ho IA, Toh HC, Ng WH, Teo YL, Guo CM, Hui KM, Lam PY (2012) Human bone marrow-derived mesenchymal stem cells suppress human glioma growth through inhibition of angiogenesis. Stem Cells. doi:10.1002/stem.1247

55. Holash J (2002) VEGF-Trap: a VEGF blocker with potent antitumor effects. Proc Natl Acad Sci USA 99(17):11393-11398

56. Holash J, Wiegand SJ, Yancopoulos GD (1999) New model of tumor angiogenesis: dynamic balance between vessel regression and growth mediated by angiopoietins and VEGF. Oncogene 18(38):5356-5362

57. Holopainen T, Saharinen P, D'Amico G et al (2012) Effects of Angiopoietin-2-blocking antibody on endothelial cell-cell junctions and lung metastasis. J Natl Cancer Inst 104(6):461-475

58. Huang H, Bhat A, Woodnutt G, Lappe R (2010) Targeting the ANGPT-TIE2 pathway in malignancy. Nat Rev Cancer 10(8):575-585

59. Huang H, Lai J-Y, Do J et al (2011) Specifically targeting Angiopoietin-2 inhibits angiogenesis, Tie2-expressing monocyte infiltration, and tumor growth. Clin Cancer Res 17(5):10011011

60. Jain RK (2005) Normalization of tumor vasculature: an emerging concept in antiangiogenic therapy. Science 307(5706):58-62

61. Jain RK, Munn LL (2000) Leaky vessels? Call Ang1! Nat Med 6(2):131-132

62. Jain RK, Carmeliet P (2012) SnapShot: tumor angiogenesis. Cell 149(6): 1408-1408.e1

63. Jin K, Zhu Y, Sun Y, Mao XO, Xie L, Greenberg DA (2002) Vascular endothelial growth factor (VEGF) stimulates neurogenesis in vitro and in vivo. Proc Natl Acad Sci USA 99(18):11946-11950

64. Jones N, Iljin K, Dumont DJ, Alitalo K (2001) Tie receptors: new modulators of angiogenic and lymphangiogenic responses. Nat Rev Mol Cell Biol 2(4):257-267

65. Jubb AM, Browning L, Campo L, Turley H, Steers G, Thurston G, Harris AL, Ansorge O (2012) Expression of vascular Notch ligands Delta-like 4 and Jagged-1 in glioblastoma. Histopathology 60(5):740-747

66. Kerbel RS (2008) Tumor angiogenesis. N Engl J Med 358(19):2039-2049

67. Kerber M, Reiss Y, Wickersheim A et al (2008) Flt-1 signaling in macrophages promotes glioma growth in vivo. Cancer Res 68(18):7342-7351

68. Keunen O, Johansson M, Oudin A et al (2011) Anti-VEGF treatment reduces blood supply and increases tumor cell invasion in glioblastoma. Proc Natl Acad Sci USA 108(9):3749-3754

69. Kim H, Koh GY (2011) Ang2, the instigator of inflammation. Blood 118(18):4767-4768

70. Kim KJ, Li B, Houck K, Winer J, Ferrara N (1992) The vascular endothelial growth factor proteins: identification of biologically relevant regions by neutralizing monoclonal antibodies. Growth Factors 7(1):53-64

71. Kim KJ, Li B, Winer J, Armanini M, Gillett N, Phillips HS, Ferrara N (1993) Inhibition of vascular endothelial growth factor-induced angiogenesis suppresses tumour growth in vivo. Nature 362(6423):841-844

72. Kioi M, Vogel H, Schultz G, Hoffman RM, Harsh GR, Brown JM (2010) Inhibition of vasculogenesis, but not angiogenesis, prevents the recurrence of glioblastoma after irradiation in mice. J Clin Invest 120(3):694-705

73. Koh YJ, Kim HZ, Hwang S-I et al (2010) Double antiangiogenic protein, DAAP, targeting VEGF-A and angiopoietins in tumor angiogenesis, metastasis, and vascular leakage. Cancer Cell 18(2):171-184

74. Korn C, Augustin HG (2012) Born to die: blood vessel regression research coming of age. Circulation 125(25):3063-3065

75. Kozin SV, Duda DG, Munn LL, Jain RK (2011) Is vasculogenesis crucial for the regrowth of irradiated tumours? Nat Rev Cancer 11(7):532

76. Kozin SV, Kamoun WS, Huang Y, Dawson MR, Jain RK, Duda DG (2010) Recruitment of myeloid but not endothelial precursor cells facilitates tumor regrowth after local irradiation. Cancer Res 70(14):5679-5685

77. Kuczynski EA, Patten SG, Coomber BL (2011) VEGFR2 expression and TGF- $\beta$ signaling in initial and recurrent highgrade human glioma. Oncology 81(2):126-134

78. Kuhnert F, Kirshner JR, Thurston G (2011) Dll4-Notch signaling as a therapeutic target in tumor angiogenesis. Vascular Cell 3(1):20

79. Kurozumi K, Ichikawa T, Onishi M, Fujii K, Date I (2012) Cilengitide treatment for malignant glioma: current status and future direction. Neurol Med Chir (Tokyo) 52(8):539-547

80. Kurz H, Korn J, Eggli PS, Huang R, Christ B (2001) Embryonic central nervous system angiogenesis does not involve bloodborne endothelial progenitors. J Comp Neurol 436(3):263-274 
81. Kurz H, Korn J, Christ B (2004) Morphogenesis of embryonic CNS vessels. Cancer Treat Res 117:33-50

82. Kümpers P, Gueler F, David S et al (2011) The synthetic Tie2 agonist peptide vasculotide protects against vascular leakage and reduces mortality in murine abdominal sepsis. Crit Care 15(5):R261

83. Lambrechts D, Storkebaum E, Morimoto M et al (2003) VEGF is a modifier of amyotrophic lateral sclerosis in mice and humans and protects motoneurons against ischemic death. Nat Genet 34(4):383-394

84. Lee S, Chen TT, Barber CL, Jordan MC, Murdock J, Desai S, Ferrara N, Nagy A, Roos KP, Iruela-Arispe ML (2007) Autocrine VEGF signaling is required for vascular homeostasis. Cell 130(4):691-703

85. Leek RD, Lewis CE, Whitehouse R, Greenall M, Clarke J, Harris AL (1996) Association of macrophage infiltration with angiogenesis and prognosis in invasive breast carcinoma. Cancer Res 56(20):4625-4629

86. Leow CC, Coffman K, Inigo I et al (2012) MEDI3617, a human anti-angiopoietin 2 monoclonal antibody, inhibits angiogenesis and tumor growth in human tumor xenograft models. Int J Oncol 40(5):1321-1330

87. Leung SY, Chan AS, Wong MP, Yuen ST, Cheung N, Chung LP (1997) Expression of vascular endothelial growth factor and its receptors in pilocytic astrocytoma. Am J Surg Pathol 21(8): 941-950

88. Lewis CE, De Palma M, Naldini L (2007) Tie2-expressing monocytes and tumor angiogenesis: regulation by hypoxia and Angiopoietin-2. Cancer Res 67(18):8429-8432

89. Liu X-M, Zhang Q-P, Mu Y-G, Zhang X-H, Sai K, Pang JC-S, Ng H-K, Chen Z-P (2011) Clinical significance of vasculogenic mimicry in human gliomas. J Neurooncol 105(2):173-179

90. Llovet JM, Peña CEA, Lathia CD, Shan M, Meinhardt G, Bruix J, SHARP Investigators Study Group (2012) Plasma biomarkers as predictors of outcome in patients with advanced hepatocellular carcinoma. Clin Cancer Res 18(8):2290-2300

91. Loges S, Schmidt T, Carmeliet P (2009) "Antimyeloangiogenic" therapy for cancer by inhibiting PIGF. Clin Cancer Res 15(11):3648-3653

92. Lu KV, Chang JP, Parachoniak CA et al (2012) VEGF inhibits tumor cell invasion and mesenchymal transition through a MET/ VEGFR2 complex. Cancer Cell 22(1):21-35

93. Machein MR, Renninger S, de Lima-Hahn E, Plate KH (2003) Minor contribution of bone marrow-derived endothelial progenitors to the vascularization of murine gliomas. Brain Pathol 13(4):582-597

94. Maisonpierre PC, Suri C, Jones PF et al (1997) Angiopoietin-2, a natural antagonist for Tie2 that disrupts in vivo angiogenesis. Science 277(5322):55-60

95. Maniotis AJ, Folberg R, Hess A, Seftor EA, Gardner LM, Pe'er J, Trent JM, Meltzer PS, Hendrix MJ (1999) Vascular channel formation by human melanoma cells in vivo and in vitro: vasculogenic mimicry. Am J Pathol 155(3):739-752

96. Matsubara T, Kanto T, Kuroda S et al (2012) TIE2-expressing monocytes as a diagnostic marker for hepatocellular carcinoma correlated with angiogenesis. Hepatology. doi:10.1002/hep.25965

97. Mazzieri R, Pucci F, Moi D et al (2011) Targeting the ANG2/ TIE2 axis inhibits tumor growth and metastasis by impairing angiogenesis and disabling rebounds of proangiogenic myeloid cells. Cancer Cell 19(4):431-433

98. McDonald DM, Foss AJ (2000) Endothelial cells of tumor vessels: abnormal but not absent. Cancer Metastasis Rev 19(1-2):109-120

99. McDonald DM, Munn L, Jain RK (2000) Vasculogenic mimicry: how convincing, how novel, and how significant? Am J Pathol 156(2):383-388
100. Meadows KL, Hurwitz HI (2012) Anti-VEGF therapies in the clinic. Cold Spring Harb Perspect Med. doi:10.1101/cshperspect. a006577

101. Murdoch C, Muthana M, Coffelt SB, Lewis CE (2008) The role of myeloid cells in the promotion of tumour angiogenesis. Nat Rev Cancer 8(8):618-631

102. Narayana A, Gruber D, Kunnakkat S, Golfinos JG, Parker E, Raza S, Zagzag D, Eagan P, Gruber ML (2012) A clinical trial of bevacizumab, temozolomide, and radiation for newly diagnosed glioblastoma. J Neurosurg 116(2):341-345

103. Norden AD, Bartolomeo J, Tanaka S et al (2012) Safety of concurrent bevacizumab therapy and anticoagulation in glioma patients. J Neurooncol 106(1):121-125

104. Norden AD, Drappatz J, Wen PY (2009) Antiangiogenic therapies for high-grade glioma. Nat Rev Neurol 5(11):610-620

105. Onishi M, Ichikawa T, Kurozumi K, Fujii K, Yoshida K, Inoue S, Michiue H, Chiocca EA, Kaur B, Date I (2012) Bimodal antiglioma mechanisms of cilengitide demonstrated by novel invasive glioma models. Neuropathology. doi:10.1111

106. Oosthuyse B, Moons L, Storkebaum E et al (2001) Deletion of the hypoxia-response element in the vascular endothelial growth factor promoter causes motor neuron degeneration. Nat Genet 28(2):131-138

107. Pàez-Ribes M, Allen E, Hudock J, Takeda T, Okuyama H, Viñals F, Inoue M, Bergers G, Hanahan D, Casanovas O (2009) Antiangiogenic therapy elicits malignant progression of tumors to increased local invasion and distant metastasis. Cancer Cell 15(3):220-231

108. Pennacchietti S, Michieli P, Galluzzo M, Mazzone M, Giordano S, Comoglio PM (2003) Hypoxia promotes invasive growth by transcriptional activation of the met protooncogene. Cancer Cell 3(4):347-361

109. Piao Y, Liang J, Holmes L, Zurita AJ, Henry V, Heymach JV, de Groot JF (2012) Glioblastoma resistance to anti-VEGF therapy is associated with myeloid cell infiltration, stem cell accumulation, and a mesenchymal phenotype. Neuro Oncol. doi:10.1093/neuonc/ $\operatorname{nos} 158$

110. Plate KH (1999) Mechanisms of angiogenesis in the brain. J Neuropathol Exp Neurol 58(4):313-320

111. Plate KH, Breier G, Risau W (1994) Molecular mechanisms of developmental and tumor angiogenesis. Brain Pathol 4(3):207-218

112. Plate KH, Breier G, Millauer B, Ullrich A, Risau W (1993) Up-regulation of vascular endothelial growth factor and its cognate receptors in a rat glioma model of tumor angiogenesis. Cancer Res 53(23):5822-5827

113. Plate KH, Breier G, Weich HA, Risau W (1992) Vascular endothelial growth factor is a potential tumour angiogenesis factor in human gliomas in vivo. Nature 359(6398):845-848

114. Plate KH, Breier G, Weich HA, Mennel HD, Risau W (1994) Vascular endothelial growth factor and glioma angiogenesis: coordinate induction of VEGF receptors, distribution of VEGF protein and possible in vivo regulatory mechanisms. Int J Cancer 59(4):520-529

115. Raab S, Plate KH (2007) Different networks, common growth factors: shared growth factors and receptors of the vascular and the nervous system. Acta Neuropathol 113(6):607-626

116. Raab S, Beck H, Gaumann A, Yüce A, Gerber H-P, Plate K, Hammes H-P, Ferrara N, Breier G (2004) Impaired brain angiogenesis and neuronal apoptosis induced by conditional homozygous inactivation of vascular endothelial growth factor. Thromb Haemost 91(3):595-605

117. Rapisarda A, Melillo G (2012) Overcoming disappointing results with antiangiogenic therapy by targeting hypoxia. Nat Rev Clin Oncol 9(7):378-390

118. Reis M, Czupalla CJ, Ziegler N et al (2012) Endothelial Wnt/ßcatenin signaling inhibits glioma angiogenesis and normalizes 
tumor blood vessels by inducing PDGF-B expression. J Exp Med 209(9):1611-1627

119. Ribatti D, Djonov V (2012) Intussusceptive microvascular growth in tumors. Cancer Lett 316(2):126-131

120. Ricci-Vitiani L, Pallini R, Biffoni M et al (2010) Tumour vascularization via endothelial differentiation of glioblastoma stemlike cells. Nature 468(7325):824-828

121. Risau W (1997) Mechanisms of angiogenesis. Nature 386(6626):671-674

122. Roca C, Adams RH (2007) Regulation of vascular morphogenesis by Notch signaling. Genes Dev 21(20):2511-2524

123. Rodriguez FJ, Orr BA, Ligon KL, Eberhart CG (2012) Neoplastic cells are a rare component in human glioblastoma microvasculature. Oncotarget 3(1):98-106

124. Rosenstein JM, Krum JM, Ruhrberg C (2010) VEGF in the nervous system. Organogenesis 6(2):107-114

125. Ruiz de Almodovar C, Lambrechts D, Mazzone M, Carmeliet $P$ (2009) Role and therapeutic potential of VEGF in the nervous system. Physiol Rev 89(2):607-648

126. Scaringi C, Minniti G, Caporello P, Enrici RM (2012) Integrin inhibitor cilengitide for the treatment of glioblastoma: a brief overview of current clinical results. Anticancer Res 32(10): 4213-4223

127. Schanzer A, Wachs F-P, Wilhelm D, Acker T, Cooper-Kuhn C, Beck H, Winkler J, Aigner L, Plate KH, Kuhn HG (2004) Direct stimulation of adult neural stem cells in vitro and neurogenesis in vivo by vascular endothelial growth factor. Brain Pathol 14(3):237-248

128. Scholz A, Lang V, Henschler R et al (2011) Angiopoietin-2 promotes myeloid cell infiltration in a $\beta_{2}$-integrin-dependent manner. Blood 118(18):5050-5059

129. Sennino B, McDonald DM (2012) Controlling escape from angiogenesis inhibitors. Nat Rev Cancer 12(10):699-709

130. Sennino B, Ishiguro-Oonuma T, Wei Y et al (2012) Suppression of tumor invasion and metastasis by concurrent inhibition of c-Met and VEGF signaling in pancreatic neuroendocrine tumors. Cancer Discov 2(3):270-287

131. Seystahl K, Weller M (2012) Is there a world beyond bevacizumab in targeting angiogenesis in glioblastoma? Expert Opin Investig Drugs 21(5):605-617

132. Shabo I, Olsson H, Sun X-F, Svanvik J (2009) Expression of the macrophage antigen CD163 in rectal cancer cells is associated with early local recurrence and reduced survival time. Int $\mathbf{J}$ Cancer 125(8):1826-1831

133. Shalaby F, Rossant J, Yamaguchi TP, Gertsenstein M, Wu XF, Breitman ML, Schuh AC (1995) Failure of blood-island formation and vasculogenesis in Flk-1-deficient mice. Nature 376(6535):62-66

134. Shweiki D, Itin A, Soffer D, Keshet E (1992) Vascular endothelial growth factor induced by hypoxia may mediate hypoxiainitiated angiogenesis. Nature 359(6398):843-845

135. Sica A, Schioppa T, Mantovani A, Allavena P (2006) Tumourassociated macrophages are a distinct M2 polarised population promoting tumour progression: potential targets of anti-cancer therapy. Eur J Cancer 42(6):717-727

136. Sikkema AH, de Bont ESJM, Molema G, Dimberg A, Zwiers PJ, Diks SH, Hoving EW, Kamps WA, Peppelenbosch MP, den Dunnen WFA (2011) Vascular endothelial growth factor receptor 2 (VEGFR-2) signalling activity in paediatric pilocytic astrocytoma is restricted to tumour endothelial cells. Neuropathol Appl Neurobiol 37(5):538-548

137. Sitohy B, Nagy JA, Dvorak HF (2012) Anti-VEGF/VEGFR therapy for cancer: reassessing the target. Cancer Res 72(8):1909-1914

138. Sorensen AG, Emblem KE, Polaskova P et al (2012) Increased survival of glioblastoma patients who respond to antiangiogenic therapy with elevated blood perfusion. Cancer Res 72(2):402407
139. Steidl C, Lee T, Shah SP et al (2010) Tumor-associated macrophages and survival in classic Hodgkin's lymphoma. N Engl J Med 362(10):875-885

140. Storkebaum E, Lambrechts D, Dewerchin M et al (2005) Treatment of motoneuron degeneration by intracerebroventricular delivery of VEGF in a rat model of ALS. Nat Neurosci $8(1): 85-92$

141. Stratmann A, Risau W, Plate KH (1998) Cell type-specific expression of Angiopoietin-1 and Angiopoietin-2 suggests a role in glioblastoma angiogenesis. Am J Pathol 153(5):1459-1466

142. Thompson EM, Frenkel EP, Neuwelt EA (2011) The paradoxical effect of bevacizumab in the therapy of malignant gliomas. Neurology 76(1):87-93

143. Tung JJ, Tattersall IW, Kitajewski J (2012) Tips, stalks, tubes: Notch-mediated cell fate determination and mechanisms of tubulogenesis during angiogenesis. Cold Spring Harb Perspect Med 2(2):a006601

144. Valenzuela DM, Griffiths JA, Rojas J et al (1999) Angiopoietins 3 and 4: diverging gene counterparts in mice and humans. Proc Natl Acad Sci USA 96(5):1904-1909

145. van Agtmaal EL, Bierings R, Dragt BS, Leyen TA, FernandezBorja M, Horrevoets AJG, Voorberg J (2012) The shear stressinduced transcription factor KLF2 affects dynamics and Angiopoietin-2 content of Weibel-Palade bodies. PLoS One 7(6):e38399

146. Verheyen A, Peeraer E, Nuydens R et al (2012) Systemic antivascular endothelial growth factor therapies induce a painful sensory neuropathy. Brain 135(Pt 9):2629-2641

147. Vredenburgh JJ, Desjardins A, Herndon JE et al (2007) Bevacizumab plus irinotecan in recurrent glioblastoma multiforme. J Clin Oncol 25(30):4722-4729

148. Wang R, Chadalavada K, Wilshire J, Kowalik U, Hovinga KE, Geber A, Fligelman B, Leversha M, Brennan C, Tabar V (2010) Glioblastoma stem-like cells give rise to tumour endothelium. Nature 468(7325):829-833

149. Wick A, Wick W, Waltenberger J, Weller M, Dichgans J, Schulz JB (2002) Neuroprotection by hypoxic preconditioning requires sequential activation of vascular endothelial growth factor receptor and Akt. J Neurosci 22(15):6401-6407

150. Wong AL, Haroon ZA, Werner S, Dewhirst MW, Greenberg CS, Peters KG (1997) Tie2 expression and phosphorylation in angiogenic and quiescent adult tissues. Circ Res 81(4):567-574

151. Xu L, Duda DG, di Tomaso E et al (2009) Direct evidence that bevacizumab, an anti-VEGF antibody, up-regulates SDF1alpha, CXCR4, CXCL6, and neuropilin 1 in tumors from patients with rectal cancer. Cancer Res 69(20):7905-7910

152. Yan M, Callahan CA, Beyer JC, Allamneni KP, Zhang G, Ridgway JB, Niessen K, Plowman GD (2010) Chronic DLL4 blockade induces vascular neoplasms. Nature 463(7282):E6-E7

153. Yang X, Cepko CL (1996) Flk-1, a receptor for vascular endothelial growth factor (VEGF), is expressed by retinal progenitor cells. J Neurosci 16(19):6089-6099

154. You W-K, Sennino B, Williamson CW, Falcón B, Hashizume H, Yao L-C, Aftab DT, McDonald DM (2011) VEGF and c-Met blockade amplify angiogenesis inhibition in pancreatic islet cancer. Cancer Res 71(14):4758-4768

155. Yue W-Y, Chen Z-P (2005) Does vasculogenic mimicry exist in astrocytoma? J Histochem Cytochem 53(8):997-1002

156. Zagzag D, Zhong H, Scalzitti JM, Laughner E, Simons JW, Semenza GL (2000) Expression of hypoxia-inducible factor 1alpha in brain tumors: association with angiogenesis, invasion, and progression. Cancer 88(11):2606-2618

157. Zhang BC, Gao J, Wang J, Rao ZG, Wang BC, Gao JF (2011) Tumor-associated macrophages infiltration is associated with peritumoral lymphangiogenesis and poor prognosis in lung adenocarcinoma. Med Oncol 28(4):1447-1452 